\title{
Government Influence on Patient Organizations
}

\author{
Hester M. Van de Bovenkamp • \\ Margo J. Trappenburg
}

Published online: 28 August 2010

(C) The Author(s) 2010. This article is published with open access at Springerlink.com

\begin{abstract}
Patient organizations increasingly play an important role in health care decision-making in Western countries. The Netherlands is one of the countries where this trend has gone furthest. In the literature some problems are identified, such as instrumental use of patient organizations by care providers, health insurers and the pharmaceutical industry. To strengthen the position of patient organizations government funding is often recommended as a solution. In this paper we analyze the ties between Dutch government and Dutch patient organizations to learn more about the effects of such a relationship between government and this part of civil society. Our study is based on official government documents and existing empirical research on patient organizations. We found that government influence on patient organizations has become quite substantial with government influencing the organizational structure of patient organizations, the activities these organizations perform and even their ideology. Financing patient organizations offers the government an important means to hold them accountable. Although the ties between patient organizations and the government enable the former to play a role that can be valued as positive by both parties, we argue that they raise problems as well which warrant a discussion on how much government influence on civil society is acceptable.
\end{abstract}

Keywords Civil society - Government influence $\cdot$ Health care decision-making · Patient organizations

H. M. Van de Bovenkamp ( $\square)$

Institute of Health Policy and Management, Erasmus University Rotterdam,

Postbus 1738, 3000 DR Rotterdam, The Netherlands

e-mail: vandebovenkamp@bmg.eur.nl

M. J. Trappenburg

Utrecht School of Governance, Utrecht University, Utrecht, The Netherlands

M. J. Trappenburg

University of Amsterdam, Amsterdam, The Netherlands 


\section{Introduction}

In the last two decades many western welfare states have granted their citizens more choice and more influence in the provision of public services (housing, education, home help, health care) be it for democratic reasons (people should have a say in whatever affects them), for reasons of efficiency (citizens should be able to point out what they really need, rather than be granted a standard provision), or to enhance the quality of service delivery (professionals learn from actively choosing and participating citizens what works and what does not) [13]. Health care is a public sector in which active participation by citizens is supposed to do a world of good. It is widely recognized that health care professionals should take leave of the traditional model of paternalist medicine in which the doctor knew what was best for his patients. They should now adhere to a model called 'shared decision-making' in which patient and doctor discuss treatment options together and then decide what to do [14].

In many modern health care systems patients not only participate in decisions concerning their own health and medical treatment. Increasingly patients also participate in all sorts of decision-making processes at the meso and macro level [4, $58,3]$. Patients participate in decision-making on many different subjects, such as government policy, medical guideline development, research agenda setting, insurer policy and provider policy [11, 17, 45, 49, 58]. The most often cited reason for patient participation is that patients bring an additional perspective based on their experiential knowledge to the table, which may improve the quality of decisions. Patient participation could thereby also increase the overall effectiveness and efficiency of the health care system, since patients might offer solutions which fit the preferences of patients better, thereby hopefully preventing mistakes and saving costs. For example when patients are well-informed compliance will improve and patients may learn how to manage their own care [8, 18, 22, 23, 26]. Patient participation is also proposed for democratic reasons. Democratic legitimacy would increase when patients participate; parties who reap the benefits or suffer the consequences from certain decisions ought to have a say in the process. Participation might also have an empowerment effect on those who participate; patients who are given a say in policy processes acquire a sense of self-efficacy [5, $11,22,58]$. In short, the expectations of patient participation in health care decisionmaking are high. Research shows, however, that not all expectations are met $[6,11$, $49,55,58]$. Patients have difficulty in actually influencing the process. Sometimes patient participation is mere tokenism [49] and at other times patients are put to instrumental use by more powerful actors in health care, such as care providers, insurers and guideline development organizations [24, 58].

According to researchers as well as policy makers, the position of patients can be strengthened when they are organized. Civil society organizations such as patient organizations could play an important role in facilitating democracy and bringing the interests of certain groups to the fore [4, 16, 41]. However, the difficulties encountered with regard to individual participation seem to pop up also when participation takes place through patient organizations: representatives of patient organizations may also be manipulated, and representatives of patients do not 
always feel able to really influence decision-making processes [4, 3, 58]. It is therefore argued by policy makers, patient organizations and researchers that patient organizations should professionalize in order to strengthen their position $[4,34,50]$. To professionalize patient organizations need money. Often membership dues are insufficient to finance paid staff members. If membership dues are too high, patients will choose to do without membership, as much of the information which used to be provided by patient organizations is now freely available on the internet [36]. Hence patient organizations have to search for additional funds. One way of increasing their financial means is through donations by the pharmaceutical industry. However, this strategy is heavily contested, since accepting money from the pharmaceutical industry may threaten the organizations' independence and may increase the danger of being put to instrumental use [3, 27, 32]. As the input of patients and the role of patient organizations are valued by many it is therefore argued that government should subsidize these organizations to enable them to play a strong role in health care decision-making. In several countries government subsidizes patient organizations [4, 31, 35]. In this article we will explore the ties between government and patient organizations in the Netherlands to see whether this is a viable strategy to ensure patient participation in decision-making while keeping patient organizations out of the hands of the pharmaceutical industry.

Patient participation through patient organizations has perhaps gone furthest in the Netherlands [58]. Dutch patient organizations are called the official 'third party' in health care, next to health care insurers and providers. This role has been assigned to them by the Dutch government and means that they are asked to participate in many official decision-making processes to represent the patient perspective (ibid.). Patient organizations have become 'insider groups', which means that they are regarded as legitimate players by government and are consulted on a regular basis (cf [21]). At present there is a wide variety of patient organizations in the Netherlands [35, 39]. There are over 300 different organizations, about 200 of which are disease specific organizations [7]. ${ }^{1}$ Together the disease specific organizations have about half a million members [39]. Besides these organizations, there are disease group umbrella organizations ${ }^{2}$ and regional and national umbrella organizations. The members of these umbrella organizations are not individual patients but other patient organizations. All patient organizations together are often referred to as 'the patient movement' [35, 39].

Dutch patient organizations rely on several financial sources. On average $27 \%$ of the funding of disease specific organizations comes from member contributions [39]. Some patient organizations receive funding from the pharmaceutical industry. On average $8 \%$ of the budget of patient organizations that are sponsored by the industry comes from the industry [44]. Obviously, not all patient organizations are sponsored. Some organizations are simply not interesting for pharmaceutical companies because they represent patients who suffer from a disease or affliction

\footnotetext{
${ }^{1}$ Examples of disease specific organizations are the Parkinson Association, the Epilepsy Association and the Lung Cancer Foundation.

${ }^{2}$ For example the Lung Cancer Foundation and other cancer organizations are part of the Dutch Cancer Federation (NFK).
} 
that cannot be cured by medication. Other patient organizations (like the client organization for mental health patients) do not want to be sponsored by the pharmaceutical industry on principle.

There has been quite a lot of debate, also in the media, about the ties between patient organizations and the pharmaceutical industry, which are generally disapproved of $[9,50]$. In response to this situation some members of Parliament argued that these financial ties are undesirable and that government funding should increase to prevent undesirable connections [53]. In the Netherlands government subsidies were already granted to patient organizations in the 1980s. Today government subsidies constitute $46 \%$ of the income of disease specific organizations [39]. Umbrella organizations also rely heavily on government subsidies. The budget of national umbrella organizations like the National Patient and Consumer Platform (NPCF) mostly consists of government subsidies ${ }^{3}$ [37].

Although government funding can enable patient organizations to become stronger players in the health care field while keeping them out of the claws of the pharmaceutical industry, it does not guarantee their independence. Government subsidies also come with strings attached and put patient organizations under at least some government control [3]. In this paper we will explore what happens when patient organizations have government as their facilitator. We will answer the following research question: In what ways does the Dutch government influence patient organizations and how should the ties between government and patient organizations be assessed?

Answering this question is important for several reasons. First of all it is important to analyze what happens when patient organizations are facilitated and subsidized by government, because this is also proposed in other countries [4, 27, 31]. Our study of the Dutch case may help to reflect on the desirability of such a policy. Secondly, answering this question may be important for scholars who are interested in neo-corporatism and policy networks. To our knowledge a large part of the research on neo-corporatism and policy networks focuses on the way interest groups influence policy making and discusses whether this influence is desirable (see for instance $[1,12,28,62]$ ). We feel it might be worthwhile to consider the opposite question. How does government in such a relationship influence interest groups (in this case patient organizations) and is this influence desirable? Although policy network theorists argue that interaction between government and groups in the policy network causes two way influence relations [4] and although researchers sometimes observe that giving groups an insider status poses the danger of becoming 'servants of the centre' [21], the influence relationship from government to civil society organizations does not receive much attention in the literature. We feel it is important to learn more about the way government influences civil society groups.

In this article we will first describe the methods used in our study (Section "Methods"). Following that we will describe Dutch government policy directed at patient organizations and the response of these organizations to this policy (Section

\footnotetext{
${ }^{3}$ In addition the NPCF receives funds from their members (other patient organizations) and some of its income comes from organized activities [37].
} 
"Results"). In the "Conclusion and Discussion" section we will argue that governmental influence on patient organizations is strong in the Netherlands, that the ties between government and patient organizations have both positive and negative consequences and that the latter may be a reason for all parties involved to critically assess this situation.

\section{Methods}

To study the ties between Dutch government and Dutch patient organizations we used different research methods. First we analyzed official policy documents regarding patient organizations to gain insight into the ideas of government about these organizations. Our policy document search showed that patient organizations have been a subject of government interest from the early 1980s onwards. Our analysis therefore consists of documents from 1980 till June 2009. An overview of the policy documents used can be found in Table 1. An analytical scheme was composed after reading the documents. We scrutinized all documents on the government's ideas about: (1) the organizational structure of the patient movement, (2) the activities patient organizations should perform, (3) the ideology of patient organizations and (4) the funding and accountability of patient organizations. This enabled us to analyze different aspects of government policy toward patient organizations.

Quite a lot of empirical research has been done into patient participation and the role of patient organizations in the Netherlands. We studied this research to gain insight in (1) the activities of patient organizations, (2) patient organizations' experiences with all of these activities and (3) the way these organizations responded to government policy plans with regard to the patient movement. An overview of the studies used is presented in Table 2.

The analysis of the policy documents and the literature on patient organizations in the Netherlands provided us with a comprehensive picture of the relationship between government and the patient movement in the Netherlands.

\section{Results}

Most Dutch patient organizations were founded in the 1980s. They were founded by patients, but often in association with or supported by health care professionals (P8). Contacts between fellow sufferers, sharing information and providing peer support were generally the most important reasons for the foundation of most of these organizations (P8). People wanted information that they could understand about their own or their children's disease or condition and they wanted to share their stories and learn from other people's experiences (P8). Patient organizations provided these services which many patients and or family members felt were important to deal with their situation and which were not provided by the professional health care system. For most patient organizations interest representation was not an important part of their activities during these early years. This was 
Table 1 Overview of government policy documents analyzed

\begin{tabular}{llr}
\hline Year & Title & Code \\
\hline 1981 & Nota Patiëntenbeleid (White paper Patient Policy) & $\mathrm{G} 1$ \\
1983 & Voortgangsnota Patiëntenbeleid (Follow up white paper Patient Policy) & $\mathrm{G} 2$ \\
1988 & Tweede voortgangsnota Patiëntenbeleid (Second follow up white paper Patient Policy) & $\mathrm{G} 3$ \\
1988 & Financieel overzicht jeugdhulpverlening (Financial overview youth care) & $\mathrm{G} 4$ \\
1992 & Nota Patiënten/Consumentenbeleid (White paper Patient/consumer policy) \\
1995 & Voortgangsbrief Nota Patiënten consumentenbeleid (Follow up letter white paper Patient/ G6 \\
& consumer policy)
\end{tabular}

1995 Nota Volksgezondheidsbeleid 1995-1998 (White paper Public health policy 1995-1998) G7

1997 Jaaroverzicht Zorg 1998 (Care overview 1998)

G8

1997 Vaststelling van de begroting van de uitgaven en de ontvangsten van het Ministerie van G9 Volksgezondheid, Welzijn en Sport (XVI) voor het jaar 1998 (Assessment of the budget of expenditures and receipts of the ministry of Health, Welfare and Sports for the year 1998)

1998 Nota Marktwerking in de gezondheidszorg (White paper Market based health care)

1998 Vaststelling van de begroting van de uitgaven en de ontvangsten van het Ministerie van Volksgezondheid, Welzijn en Sport (XVI) voor het jaar 1999 (Settlement of the budget of expenditures and receipts of the ministry of Health, Well-being and Sports for the year 1999)

2000 Vaststelling van de begroting van de uitgaven en de ontvangsten van het Ministerie van Volksgezondheid, Welzijn en Sport (XVI) voor het jaar 2001 (Assessment of the budget of expenditures and receipts of the ministry of Health, Well-being and Sports for the year 2001)

2000 Vaststelling van de begroting van de uitgaven en de ontvangsten van het Ministerie van Volksgezondheid, Welzijn en Sport (XVI) voor het jaar 2001: voortgangsbrief over bundeling krachten patiënten en consumenten organisaties (Assessment of the budget of expenditures and receipts of the ministry of Health, Well-being and Sports for the year 2001: follow up letter on combining the power of patient/consumer organizations)

2000 Zorgnota 2001 (White paper Care 2001)

2001 Patiënten/consumentenbeleid: Met zorg kiezen De toerusting van patiënten en consumenten in een vraaggestuurde zorg (White paper Patient/consumer policy: Choosing with Care: the equipment of patients and consumers in a demand driven care system)

2002 Patiënten/consumentenbeleid: brief minister evaluatie en beleidsvoornemens over Fonds PGO (Patient/consumer policy: letter of the minister on the evaluation and policy resolutions concerning the $P G O$-fund)

2004 Patiënten/Consumentenbeleid: voortgangsbrief (Patient/consumer policy follow up letter)

2007 Subsidiebeleid VWS, brief minister over de toekomstige financiering van PGO-organisaties (White paper on subsidy policy of the ministry of Health, Well-being and Sports, letter on the future of financing patient organizations)

2007 Verslag schriftelijk overleg over versterking pgo-organisaties: reactie van de minister (response of the minister of Health, Well-being and Sports to questions concerning the strengthening of patient organizations)

2008 Subsidiebeleid VWS, brief minister over de toekomstige financiering van PGO-organisaties (White paper on subsidy policy of the ministry of Health, Well-being and Sports, letter on the future of financing patient organizations)

2008 Subsidiebeleid VWS, brief minister over de toekomstige financiering van PGO-organisaties (White paper on subsidy policy of the ministry of Health, Well-being and Sports, follow up letter on the future of financing patient organizations) 
Table 2 Overview of patient organization research analyzed

\begin{tabular}{llll}
\hline Year Authors & Title & Code \\
\hline 1989 Rijkschroeff, R.A.L. & $\begin{array}{l}\text { Ondersteuning van participatie in de geestelijke } \\
\text { gezondheidszorg (Participation support in mental health } \\
\text { care) }\end{array}$ & P1
\end{tabular}

2004 Nederland, T. and J.W. Duyvendak

2004 Klop, R. et al.

2004 Van Veenendaal, H. et al.

2005 Van Wersch, S.F.M. and P.A.M. Van den Akker

2005 Caron-Flinterman, J.F

2007 Schut, F.T. and D. De Bruijn

2008 Trappenburg, M.

2008 Oudenampsen, D. et al.

2008 Van de Bovenkamp, H.M. et al.

2008 Van de Bovenkamp, H.M. et al.

2008 Oudenampsen, D. et al.

2009 Sattoe, J.

2010 Van de Bovenkamp, H.M. et al.
De kunst van effectieve belangenbehartiging door de patiënten- en cliëntenbeweging. De praktijk (The art of effective interest representation by the patient and client movement: Practice)

Patiënten doen mee bij ZonMw!. (Patients participate at ZonMw!)

Patiëntenparticipatie in richtlijnontwikkeling (Patient participation in guideline development)

Cliëntenparticipatie bij multidisciplinaire richtlijnontwikkeling in de GGZ: Ervaringskennis is geen kennis!? (Client participation in multidisciplinary guideline development in mental health care: Experiential knowledge is no knowledge!?)

A new voice in science. Patient participation in decisionmaking on biomedical research health Insurance contracts and risk selection)

Genoeg is genoeg. Over gezondheidszorg en democratie (Enough is enough: on health care and democracy)

Patiënten en Consumentenbeweging in Beeld: brancherapport 2007 (A description of the Patient and Consumer movement: branchreport 2007)

Zaakwaarnemers van de patiënt (Sponsors of the patient)

Inventarisatie patiëntenparticipatie in onderzoek, kwaliteit en P11 beleid (Inventarisation patient participation in research, quality policy and policy making)

Patiënten en Consumentenbeweging in Beeld: brancherapport 2008 (A description of the Patient and Consumer movement: branchreport 2008)

Belangenbehartiging belicht: een dubbelrol voor PGOorganisaties (Interest representation: a double role for patient organizations)

Patient participation in collective health care decisionmaking: the Dutch model

different for a few radical organizations in the mental health care sector which struggled to make mental health care less medical and more democratic (P1, P8).

Once founded, patient organizations soon became a subject of government interest. Government policy was directed at influencing patient organizations in several ways. In the following subsections we will describe the government's policy to change their organizational structure, their activities, and their ideology and the response of patient organizations to each of the policy proposals. Lastly we will describe how government tried to hold patient organizations accountable through 
government funding and how this worked out for patient organizations. Interestingly the policy of the Dutch government directed at patient organizations seems to have followed a consistent path throughout the years, despite the fact that different political parties participated in government. Dutch political parties in subsequent governments seem to have had similar ideas about patient organizations.

\section{Organizational Structure}

In 1981 an important white paper, entitled Patient Policy (G1), was published in which it was argued that users of care should have a say in the provision of care in health care institutions, in regional advisory boards and in decision-making at the national level. Patient organizations were expected to play an important role in all of these decision-making arenas. However, according to this document, patient organizations were not organized in the right way to accomplish this. There were a lot of disease specific organizations that catered for members who were often too sick to participate in any kind of council. Even when their health was no obstacle to participation, they did not seem to be interested in participation, since only a small number of disease specific organizations had designated influencing policy as one of their goals. In addition it was identified that the different organizations did only sporadically work together. There were no regional organizations with a general interest in health care policy. A lack of money was considered to be an important cause of this lack of unification. Regional authorities were therefore asked to finance patient organizations in order to create and maintain regional patient platforms, which could represent the interests of patients and deliver expertise and knowledge in policy making. In the first half of the 1980s regional platforms, financed with regional governments' money, were indeed created (G3). After their creation government tried to influence these regional platforms further, for instance they were admonished to give disease specific organizations a say in their activities so as to ensure that justice was done to the diversity of the movement (G15).

In the white paper Patient Policy (G1) government not only recommended patient organizations to organize themselves at the regional level; a national platform for patients and health consumers was proposed as well. The development of such a platform would be supported by government, and financing it was considered part of this support. The national patient/consumer platform should be a suitable voice for patients' interests according to the government. To help position such a platform in the field it was further proposed that representatives of the platform should serve on a number of important advisory councils, such as the National Council for Public Health. In 1983 a national platform for patients and consumers, the LPCP (Landelijk Patienten en Consumenten Platform), was founded which employed activities on general patient interest representation (P8).

In 1988 a follow up white paper on Patient Policy was published (G3). In this paper it was argued that government policy should be directed at strengthening the position of patient organizations further by making sure that they increasingly worked together. To strengthen patient organizations' position subsidies would be increased. In another white paper on patient and consumer policy, published in 1992, the government announced that the kind of extensive participation in 
decision-making bodies expected from patient organizations required a patient movement organized more clearly and more consistently. Ideally there should be one identifiable powerful organization which could count on broad support (G5). Government wanted an umbrella organization that would represent a larger part of the patient movement than the LPCP did. This wish was granted almost immediately. In 1992 the National Patient and Consumer Federation (NPCF), a broader federation of coalitions of patient organizations, replaced the LPCP (G6). The national federation and some other organizations that provided patient organizations with support would be financed by the government, after having been evaluated on efficacy and cooperation possibilities (G5).

Government's interference with the organizational structure did not end with the push for umbrella organizations; the patient movement was also asked to make sure that there was no overlap between organizations. An evaluation of the working method of the NPCF was announced as a way to support the development of new strategies in the middle of the 1990s (G6). By the end of the 1990s the government announced that a trajectory would be started, the goal of which would be obligatory collaboration or integration of existing patient platforms (G11). In a letter to parliament the minister of health care announced that she had asked a consultancy firm to investigate how the NPCF and two other national platform organizations, the Council for the disabled and the Union for the organizations of the chronically ill, cooperated to see if there was any overlap or perhaps white spots in their activities (G13). Before the investigation was really carried out the Council for the disabled and the Union for the organizations of the chronically ill put two and two together and decided to merge (P8), which was applauded by the government (G15).

In 2001 the white paper Choosing with Care was published. Again the future of patient organizations was discussed and again government expressed its desire that they should present a united front and that the department of health would keep a check on the way the different levels of the patient movement worked together (G15). This push toward more cooperation remained on the policy agenda throughout the years (G17, G18). In 2009 the government announced that it would like the different umbrella organizations to form one organization. The umbrella organizations have agreed to think about this which pleases the minister of health care (G20). Cooperation increasingly dominates the agenda of patient organizations. Although many disease specific organizations still emphasize their uniqueness they start to acknowledge the need to work together, because of the ever increasing government induced demand for interest representation activities. Working together can strengthen their position, they feel. Moreover, it gives them the opportunity to professionalize. One patient organization alone cannot afford to hire paid staff, but several organizations combined can, especially if working together is rewarded financially (P10). For example, several patient organizations concentrating on heart conditions have decided to merge in order to strengthen their interest representation activities (P13). Other patient organizations also increasingly work together in their interest representation tasks and in sharing information (P12).

In sum, we can say that the government successfully tried to change the organizational structure of the patient movement several times and continues its attempts to influence this structure. 


\section{Activities}

Government policy also included recommendations for patient organizations to steer their activities. These directions became increasingly more specific. At first, the original activities of patient organizations, providing information and peer support, were valued greatly by the Dutch government (see for instance G6). In addition, however, government would like them to perform more interest representation activities. In the beginning of the 1980s the lack of interest of many patient organizations in policy issues was identified with regret (G1). According to the government patient organizations should become much more active in formal decision-making processes.

In the late 1980s, government observed that many patient organizations had indeed become active in committees and councils. However, according to the government this still did not happen enough (G3). To facilitate their role in decision-making government awarded patient representatives seats in official advisory councils and pushed for their participation in decision-making on all kinds of levels (G3). Government also emphasized the importance of patient involvement in contacts with providers and insurers (G5, G6). According to the government, patient organizations should focus on influencing insurer and provider policy as the 'third party' in health care, next to providers and insurers. However, since government still played an important role in health care policy making it was argued that patient organizations should critically follow government policy as well (G6). The 'third party' discourse continues to dominate policy documents in the following years. Consecutive ministers of health care announced that patient organizations should be an equal partner to health care providers, insurers and the government (G14, G19). Patient organizations on their part report that although providing information and peer support is still important, interest representation, such as trying to improve the quality of care, stimulating scientific research and purchasing health care, has become very important as well and that this task has grown into a significant part of their activities. All other actors in health care, insurers, providers, government, researchers, intermediary and supervisory organizations, consult with patient organizations in one form or the other (P8, P9, P10, P11, P12, P14).

Government also increasingly specified which subjects patient organizations should become interested in. In the late 1980s for example government saw a role for patient organizations in decision-making on medical research. Government felt that its own role in scientific research should be more distant than before. Instead societal organizations ought to be involved in scientific research, including patient/ consumer groups. According to the government this would lead to large societal support and enhance the implementation of the results of scientific research $(\mathrm{G} 4)$. A spokesperson of the patient movement was awarded a seat on the Council of Health research, which has an important task in advising government on research priorities. Some years after this, patient representatives were asked as official reviewers to comment on research proposals at ZonMw, the organization responsible for dividing the governmental research budget in the health care sector (P3, P11). Other initiatives include consultation of patient representatives by researchers (researchers are required to seek patients' advice if they want to be eligible for ZonMw research 
funds) and participation of patients in research committees (P6, P8). Some patient organizations also perform research on their own. Thus, patient organizations have taken these new tasks on board and try to influence research in different ways (P8, P11, P12).

Guideline development was another area of decision-making government felt to be important for patient organizations. In 1995 the minister stated that she would support the involvement of patient representatives in medical guideline development because of the experiential knowledge they would bring to the tables where professional guidelines were discussed. Patient organizations should want to and dare to carry joint responsibility for the content and the application of guidelines (G7) used by medical professionals to provide care according to the best medical knowledge. Many patient organizations do indeed participate in guideline development since the end of the 20th century. They are asked to partake in guideline development groups, with professionals, researchers and other experts in the field, by organizations that develop such guidelines and they try to do so as much as possible (P4, P10, P11).

In 2006 a new health care insurance system was introduced in the Netherlands, based on managed competition (see also [54]). This new system provided patient organizations with new participation possibilities. Patient organizations, as the official third party in health care, are expected to become a countervailing power to health care professionals and health care insurers on the health care market (G14). Patient organizations should make sure that patient preferences are central in the provision of care $(\mathrm{G} 10, \mathrm{G} 18)$. In response to this governmental desire, patient organizations now consult with both health care insurers and providers to improve the quality of care that is provided. For example, although not standard practice yet, insurers consult with patient organizations to learn more about criteria for health care purchasing. Patient organizations also participate in quality projects of providers and insurers to identify points for improvement in hospital care. In addition some patient organizations try to monitor the quality of care that is provided, award quality marks to care institutions that provide care according to their criteria, and take action when they find instances of insufficient health care provision (P10). The new health insurance act also allowed and expected patient organizations to organize their membership into insurance purchasing groups to negotiate better benefits for their members. Some patient organizations immediately put this into practice. In 2007 around 50 collective contracts were closed by patient organizations (P7) and more patient organizations are trying to negotiate similar contracts. However, so far the contents of the collective contracts were not impressive. Patient organizations have not been able to negotiate contracts which offer better care for their members (P10, P14).

More activities of patient organizations were not only expected on the national level but on the local level as well. With the introduction of the Social Support Act (Wet maatschappelijke ondersteuning, Wmo) in 2007 patient organizations are expected to represent the interest of patients in municipalities. This act decentralizes certain activities concerning the provision of care. Municipalities are obligated to involve a number of stakeholders, amongst others patient organizations. Since this is a recent development it remains to be seen how this policy works out in practice. It 
is clear, however, that at least a number of patient organizations do try to fulfill their expected role on the local level (P8, P9). A little over a quarter of them now have contacts with local government (P9).

In short, more and more tasks were assigned to and expected of patient organizations, which most organizations try to take on board. Patient organizations report that they participate in as many decision-making processes as possible, which has led to a problem of overload. They are asked to participate in so many decisionmaking procedures that they cannot cope with the demand. This applies especially to smaller organizations, but larger organizations also experience this problem. Nonetheless many patient organizations express a wish for even more participation possibilities and increased government funding to enable them to play the role that is expected from them (P8, P14, G18). However, the fact that all their efforts do not lead to the powerful position they hoped for does lead to some frustration amongst patient organizations (P5, P8, P14). Although they have been given many opportunities to participate, patient organizations still experience a lot of difficulty in actually influencing decisions.

The case of patient organizations in the Netherlands shows that access does not necessarily equal influence (P14). For sure, there are shining examples of patient organizations that managed to change health care for the better. The HIV association and the Breast Cancer Association managed to change policy concerning medication distribution, through lobbying and media utilization. The Association for Muscular Diseases is generally acknowledged as a driving force behind medical research in this area, since they are able to bring together experts and patients for diseases that only strike a small number of people. But in general patient organizations find it hard to influence decision-making processes. Most of the interest representation activities consist of taking part in formal decision-making procedures. This participation model can be described as neo-corporatist. Patient organizations attribute their lack of influence to the fact that they remain in a dependent position in this model; other actors in the field do not really need them to make decisions. So whenever there is disagreement, the more powerful actors in health care, such as insurers and providers, can easily disregard patient organization representatives and continue anyway. Patient organizations can do little to prevent this (P14). This effect is reported on participation in decision-making processes with different actors. For instance, in the negotiations with insurers (patient organizations operating as insurance purchasing groups), in decision-making processes on research and in guideline development project teams (P5, P8, P10, P14). Patient organizations sometimes feel that other actors can show off with a seal of approval (approved by patient organization $\mathrm{X}$ !) while not allowing them a real say in the process (P10, P14).

\section{Ideology}

Dutch government did not only steer the kind of activities patient organizations should perform, it also tried to determine in advance what their input should be in carrying out these participation activities; it tried to influence patient organizations' ideology. 
From the very beginning government wanted patient organizations to be critical towards the medical profession. Organizations of health care professionals historically have a strong position in health care and patient organizations should be supported to counter this position (G1, G3). However, most patient organizations were founded in association with and supported by professional health care workers, which led to a less than critical attitude among disease specific organizations according to government (G1). Since health care workers and patients had 'structural intrinsically conflicting interests' this situation was deemed undesirable (G1). In the early days of the patient movement a more critical attitude toward the medical profession was displayed by general patient organizations (such as the non disease specific Association for Child and Hospital), by client organizations in mental health care and by general consumer organizations (which were active in representing the interests of consumers on all kinds of markets besides health care) (G1). The national platform that was founded in 1983 consisted of these critical organizations (P8), which meant that the national platform of patients had the desired critical attitude towards the health care profession.

In several policy documents the government emphasized that patient organizations should be 'professionalized' and that they should improve their expertise $(\mathrm{G} 2$, G5, G12, G15, G17, G18). This professionalization also potentially affects the input of patient organizations since it implies a shift in focus of these organizations, while different knowledge and expertise is considered to be important. What the government meant by professionalization was not always explained clearly, but it seemed to entail at the least that organizations should have a proper administration, that they ought to formulate policy goals, evaluate whether these goals were accomplished and that they ought to be able to participate in the decision-making bodies that the government wanted to open up for them. This meant that they should have highly qualified volunteers, or hire educated personnel. Apparently the experiential knowledge of the average patient active in a patient organization could not deliver the input that government wanted from patient organizations. In consultation with the NPCF government announced a coordinated education program to improve patient organizations' expertise (G5). In 2002 the government concluded that the process of professionalization had taken place according to plan (G16). An example of this professionalization can be seen in the board of the umbrella organization NPCF. The board no longer consists of (former) patients with experiential knowledge; several of its present members are business managers and economists (www.npcf.nl). What the effect of this composition is has not been properly researched yet. However, it is likely that the strong support for a market based health care system of the NPCF (the National Patient and Consumer Federation was among the more ardent supporters of the plan) had something to do with the composition of the board. Many disease specific organizations are trying very hard to professionalize as well. It is agreed that participants need to be able to look beyond their individual experiences, have strong negotiating skills and organizational, financial, medical and scientific knowledge to be able to talk to the other actors at the negotiating table (P14). These organizations are therefore educating their volunteers, they try to recruit highly educated volunteers and increasingly hire professional employees, who are not expert patients themselves but have knowledge 
about interest representation (P2, P8, P10, P14). A little over half of the disease specific patient organizations still only work with volunteers. All other disease specific organizations and the umbrella organizations have professionals working for them to support their work (P9). Recently the minister of health care concluded that this professionalization is not yet finished and more money is promised, so the patient movement can become a more powerful, equal party in health care (G18).

\section{Funding and Accountability}

The Dutch government has put a lot of effort in steering patient organizations. Funding these organizations has been the most important instrument to do so. Patient organizations have increasingly been subsidized by the government from the 1980s onwards (G1, G3, G5, G8, G15, G16, G18). In 1996 the government created a special fund to distribute subsidies among patient organizations (G9, G16). In the beginning of the twenty-first century the amount of money to be distributed was raised several times because of the new health care system in which a more important role was expected of patient organizations (G10, G18).

Subsidizing patient organizations gave government the means to enforce compliance and accountability. Granting subsidies entailed detailed supervision on how the money was spent. Over the years the requirements connected to the subsidies became increasingly far reaching. First of all patient organizations were required to be transparent and representative (G15). Government wanted them to especially focus on involving ethnic minorities for instance. In the policy paper Choosing with Care it was explicitly stated that if patient organizations would not comply with the government's demands the minister would reconsider the subsidy structure of the movement (G15). The financing structure has been changed several times over the years to increase governmental influence. Since 2001 the government has contemplated financing patient organizations "on the basis of performance" (G15). This financing structure was put into practice in 2006 and developed further in 2007 (G18). Financing on the basis of performance meant that patient organizations had to prove that they really performed the activities that were expected from them. This accountability regime enlarged government control.

In the 2009 government plans, subsidies for patient organizations consist of different parts. The first part is a basic subsidy, a second part is granted for "development purposes". The criteria for this latter part of the subsidy are not clear yet; they will be established in consultation with "the field", i.e. with representatives of patient organizations (G21). Thirdly patient organizations can apply for project subsidies. If they want to apply for a project subsidy they must draw up a 4-year plan in which they explain how their activities fit within certain subjects delineated by the government (G19).

Almost all patient organizations apply for government funding (P8). Moreover, patient organizations want government subsidies to increase because they feel they need more money to be able to perform the tasks that are expected from them (P8, P10). Since they are expected to play this role by the government, they tend to think that the government should enable them to do so by giving them the necessary financial means. And as they need these finances to perform all their activities they 
accept that they have to respond to all kinds of government demands to receive these subsidies. Research shows that patient organizations are satisfied with the opportunities to influence decision-making given to them by the government. The great majority of patient organizations comply with governmental demands without protest (P8).

\section{Conclusion and Discussion}

Patient organizations today are quite different from the ones that were founded in the 1980s. Their organizational make-up, their activities and their input in decisionmaking have changed substantially. We have shown that these changes have been influenced if not brought about by the Dutch government. Government policy granted patient organizations an insider group status. Government policy directed at patient organizations has had a consistent focus over the years. Subsequent governments of different political colour have supported patient organizations so as to strengthen the position of patients and to transform them into a countervailing power to health care providers and insurers. This policy consistency can be explained by the fact that strengthening the position of patients is broadly considered to appeal to certain values such as self development and democracy, examples of post material interests which many Dutch political parties support. This may apply less to the moderately conservative Christian Democratic Party which was part of government during most of this period, but then this party has always cherished civil society which may explain their ongoing interest in patient organizations. Thus supporting patient organizations fits nicely with widely shared values of different political parties. Furthermore, the fact that subsequent governments aimed to change the health care system into a more demand driven system during this entire period can also explain the continuous interest in patient organizations. The system based on regulated competition that was introduced in 2006 was the result of a reform process that had been on the agenda for over 20 years [25]. Strengthening the position of patient organizations was and is seen as an important part of the reform process.

Although government itself at one point announced that it should practice restraint in influencing patient organizations [51,52] we conclude that its influence on patient organizations has been quite substantial. Of course it is widely acknowledged that the opportunity structure of civil society organizations is influenced by government. It can create incentives for them to behave in certain ways $[21,35]$. In this case however government influence is far reaching and does more than just create opportunities to influence decision-making in a certain way. Government successfully steered different aspects of patient organizations by subsidizing and facilitating them. Most patient organizations seem to resign to the new procedures. The government has given them a position they can hardly refuse as they are given the opportunity to represent the interests of their members and their 'constituency' (people who suffer from a disease but did not join the patient organization) in all kinds of decision-making processes. In order to reach this position they professionalize, they merge, they present a united front and they 
perform the administrative tasks required to apply for subsidy money. Many patient organizations even ask for more participation possibilities and more government subsidies to enable them to perform all the activities expected from them [58, 50, 56]. They acknowledge that they are not an equal party in health care as the government would like them to be, and ask for more support to realize their full potential. Numerous intermediary organizations, researchers and members of parliament support this plea to increase participation possibilities and expand support for patient organizations. Most research into the current state of patient participation in the Netherlands concludes that the process is 'starting off', but that more opportunities should be created, more support should be granted and that patient organizations should professionalize further (see for instance [20, 34, 39, 60]).

Although we sympathize with certain aspects of this evaluation, we feel that more attention should be paid to the disadvantages of governmental interference in civil society. We will therefore discuss both the positive and negative aspects in the following section.

The situation we described in our article has some positive effects for the different actors involved. A first positive aspect relates to the importance of public accountability. From a societal (taxpayer's) perspective, one may appreciate that government keeps a check on how public money is spent. Public accountability is an important aspect of democratic governance; it is generally felt that government needs to be transparent about its decisions and its expenditures [10]. Thus, it is important that patient organizations are transparent about how they spend public money.

Secondly, organizing patient participation has proven a useful and successful steering mechanism for the Dutch government. It was part of their policy to strengthen the position of patients and reform the health care system into a demand driven system, with an aim to make it more effective and democratic. In such a system patients should behave like consumers who critically assess the care that is provided and who have a voice in decisions concerning their care. Patient organizations can play an important role in critically following health care, since it is felt that individual patients cannot do this alone. Strong patient organizations could be a countervailing power to the other parties on the health care market. It is also felt that strengthening patient organizations makes health care decision-making more democratic, since important stakeholders in health care are present at the decision-making table. Interestingly strong patient organizations could also cause problems for government should they oppose government policy. Nevertheless the government has repeatedly asked patient organizations to follow its own role critically. One might conclude that the government has created its own friendly opposition by subsidizing and facilitating patient organizations, which may be a good thing from the government's perspective (although not necessarily from the patients' point of view). Patient organizations might feel free to follow the government critically (having been invited to do so after all), but the fact that they are not known to vehemently oppose the government $[35,50,56]$, could also be caused by this same policy. After all it seems harsh and less than polite to really bite 
the hand that feeds you. From a Machiavellistic perspective one may applaud this strategy as very effective.

The situation can also be valued as positive because it gives patients the opportunity to influence health care decision-making. Strengthening the position of patients in relation to health care providers, insurers and the pharmaceutical industry has been recognized as important in many countries [3, 13, 22]. One of the means to do this is offering patient organizations the opportunity to speak on behalf of patients. Government policy in the Netherlands has given patient organizations access to all kinds of decision-making structures which otherwise would have been closed to them, or at least more difficult to conquer. Since one of the goals of patient organizations now is, albeit through government interference, representing the interests of their members, the participation possibilities facilitated by the government give them a means to accomplish their goal. Although patient organizations find it hard to really influence decision-making [58], thanks to government facilitation patient organizations in the Netherlands now at least have the opportunity to voice their opinion on different subjects.

Another advantage is the empowerment of people who are active in these organizations. Participation is a way to increase their social capital $[58,50]$. People otherwise left out in society are integrated and can participate in society again (ibid.). The active role of patient organizations therefore has positive effects on the individual level as well and can be part of a more general policy trend to create involved democratically skilled citizens [13, 41].

A last obvious advantage of government sponsorship is that this policy at least partly prevents influence by the pharmaceutical industry. Without government subsidies patient organizations would have to search for other financial sources and turning to the pharmaceutical industry for funds would then be a much more attractive option. This might leave the door open for patient organizations to be influenced by the industry. Sponsorship by the pharmaceutical industry is frowned upon both in the Netherlands and in other countries because of the danger of being influenced [9, 27, 32]. Although the exact influence of industry on patient organizations is often not clear, and it is possible that their interests coincide, there is a lot of uneasiness about this relationship which can negatively affect the perception of the ability of patient organizations to speak for patients [27]. Therefore it may be important to avoid such ties.

Thus there are several reasons to evaluate the policy course in the Netherlands positively, particularly when we compare this situation to other countries. In comparison patient organizations are strongly embedded in decision-making structures in the Netherlands. However, there are also negative effects attached to Dutch government policy regarding patient organizations.

First of all the effect of goal replacement can be identified. Patient organizations have changed substantially over the years. Most of them were founded to provide peer support and information for fellow sufferers. At present an important part of the work of patient organizations consists of interest representation in formal decision-making structures. Whereas individual contacts with fellow sufferers were the primary focus before, at present patient representatives find themselves 
participating in all kinds of committees and project groups and producing papers to justify their expenses. Within these interest representation activities further changes can be identified. Whereas the original idea was that patients should improve the decision-making process by introducing their experiential knowledge, this is now pushed to the background due to the professionalization of patient organizations [58]. Professional staff members recruited by patient organizations now do their very best to know whatever it is that the other parties at the bargaining table know also, be it medical technical stuff, economic insights or bargaining strategies. Although this enables them to talk to the other parties at the table, it raises important representativeness issues. Professional interest groups can diminish the democratic potential of such groups, since they distance themselves from the people they claim to represent [48].

A second negative aspect is that the government's policy ties the hands of patient organizations. As was stated earlier it is difficult to criticize government policy when one receives government funding and has to meet all kinds of criteria attached to these subsidies. Their relationship with government puts patient organizations in a vulnerable position. It makes it more difficult for them to follow their own agenda and raise the issues patients really find important since they join existing structures. This applies especially when it concerns subjects that oppose government policy.

Thirdly patient organizations have become policy and strategy followers due to their institutionalized position. Institutionalization diminishes the potential of protest $[1,21]$. Because of all the possibilities to participate in formal decisionmaking processes opened up to them patient organizations are known to make little use of more oppositional strategies such as demonstrations and the use of the media [34, 50]. They follow both the agenda and the strategies proposed by the government $[50,58]$. Whether they are really able to influence decision-making in a neo-corporatist decision-making model can be questioned (ibid.). Nederland et al. show that relying on official institutional channels makes patient organizations less effective than they might otherwise be [34].

Another negative effect is a loss of empowerment. Although patient organizations provide active members with an opportunity for empowerment and with a chance to increase their social capital, an effect which was also partly created because of government policy, the policy directed at professionalizing these organizations may put this effect in jeopardy again. To be able to participate in all kinds of formal complicated decision-making procedures patient organizations now search for highly educated volunteers or professional employees, which means that not everybody can become active in a patient organization anymore [58]. The continuing government involvement and the extra government demands may undo the positive effect created by the initial government policy directed at patient organizations.

Lastly one may plausibly argue that patient organizations are being put to instrumental use by the government. Patient organizations are part of a governmental strategy to reach certain policy goals. The question is whether so much government influence on civil society is desirable. Civil society organizations are considered important for democracy because they give citizens a means to let their voices be heard [2, 15, 19, 61]. It is argued that it is important for a viable 
democracy to maintain a balance in society between the state, civil society and the market [63]. Too much government interference in civil society organizations may disrupt the balance.

\section{Lessons for the Future}

So what can we learn from the Dutch situation? Government policy directed at patient organizations in the Netherlands has positive effects. It ensures public accountability, it provides the government with a successful steering mechanism, it offers patient organizations a chance to participate in health care decision-making, it opens up opportunities for empowerment for active members of patient organizations and it keeps patient organizations largely out of the hands of the pharmaceutical industry. All of this might be sufficient reason to consider a similar policy in other countries. The downsides of the Dutch model should also carry some weight though. Too much governmental steering may lead to goal displacement in patient organizations, ties their hands, makes patient organizations agenda and strategy followers rather than agenda setters, undoes the empowerment effect and may put patient organizations to instrumental use. These disadvantages tell every other government that considers this strategy $[3,31]$ to proceed with caution. Of course no funding source is free of dilemmas [27] and the fact that a policy has certain disadvantages does not necessarily have to lead to the conclusion that it should be abolished. When evaluating a certain policy it is also important to consider the alternatives. In this case the alternative would be that patient organizations would have far more difficulty in gaining access to certain decisionmaking processes. It would also leave them far more vulnerable to interference from the pharmaceutical industry. The situation in many other countries shows that patient organizations in the Netherlands are comparatively well off. Government interference may well be preferable if the alternative would be sponsorship by the pharmaceutical industry. However, we feel there is no need to simply accept the disadvantages of government sponsorship because the most obvious alternative would be far worse. We think that measures can be taken to improve the situation.

An important means to do this is the creation of a more independent financial source for patient organizations. Government might consider providing patient organizations with a basic subsidy that comes with fewer strings attached. Some broad criteria could be taken into account to ensure accountability for the spending of tax payers money, such as providing some insight into the activities and why they are relevant for their members. Making legislation that ensures this subsidy for a longer period can further free patient organizations from too much government involvement. This way, patient organizations have more room to decide for themselves what they find important. They might decide to focus once more on the core tasks for which they were founded originally; peer support and providing information, the tasks many patient organizations themselves still consider to be most important [38]. Or they may decide to focus on contributing experiential knowledge in their participation activities instead of professionalizing by familiarizing themselves with the expertise of other parties. This might be quite difficult since patient organizations join long established decision-making processes which 
have certain modes of conduct. However, since listening to the patient's voice and valuing the patient's input is generally considered important in health care, this could be the way to accomplish just that. Patient organizations could also consider other influence strategies such as more activist ones instead of participating in formal decision-making procedures. Again it is important to consider the alternative; in the current situation there is access but this does not equal influence [58]. It is therefore questionable whether the goals of more effective and democratic decision-making are reached in the current situation.

Such a policy of governmental restraint would mean that government would lose an effective steering mechanism. On the other hand subsidizing civil society into obedience and compliance might be something a government in a democratic country should not be willing to do in the first place. Freedom of association is an important right in a democratic state, which can only be assured when government does not interfere with it too much. Although it is hard to pinpoint the exact boundaries to justified government assistance to civil society, practicing restraint for the sake of civil society's independence might do credit to the government [50].

Accompanying these decisions in policy practice we think it could also be worthwhile to pay scientific attention to ties between civil society and the state. This debate is important because, as stated before, our case study does not stand alone. A similar role for patient organizations is considered in other countries [3, 31]. Furthermore, similar ties between government and civil society exist in other policy sectors, for instance between government and ethnic minority organizations [30, 43]. Another example is political parties which according to some have even moved from being part of civil society to being part of the state [33]. When these organizations are seen as important for a viable democracy because they offer groups a means to influence decision-making, they should be given the opportunity to play this role. Too much government influence can prevent them from doing so. It seems high time to start a debate on the limits to government interference in civil society.

Open Access This article is distributed under the terms of the Creative Commons Attribution Noncommercial License which permits any noncommercial use, distribution, and reproduction in any medium, provided the original author(s) and source are credited.

\section{References}

1. Akkermans, T., \& Nobelen, P. W. M. (1983). Corporatisme en verzorgingsstaat. Leiden/Antwerpen: H.E. Stenfert Kroese B.V.

2. Backman, E. V., \& Smith, S. R. (2000). Healthy Organizations, Unhealthy Communities? Nonprofit Management and Leadership, 10, 355-373.

3. Baggott, R., \& Forster, R. (2008). Health consumer and patients' organizations in Europe: Towards a comparative analysis. Health Expectations, 11, 85-94.

4. Baggott, R., Allsop, J., \& Jones, K. (2005). Speaking for patients and carers: Health consumer groups and the policy process. Hampshire: Palgrave Macmillan.

5. Baker, A. (2007). Patient involvement in a professional body: Reflections and commentary. Journal of Health Organization and Management, 21, 460-469.

6. Barnard, A., Carter, M., Britten, N., Purtell, R., Wyatt, K., \& Ellis, A. (2005). The PC11 report summary: An evaluation of consumer involvement in the London Primary Care Studies Programme. Peninsula Medical School Universities of Exeter and Plymouth. 
7. Berk, M., Van der Steeg, H., \& Schrijvers, G. (2008). Stille kennis: patiënten- en gehandicaptenorganisaties waardevolle bronnen van informatie. Julius Centrum voor Gezondheidswetenschappen en Eerstelijnsgeneeskunde. Utrecht: UMC Utrecht.

8. Boote, J. D., Telford, R., \& Cooper, C. L. (2002). Consumer involvement in health research: A review and research agenda. Health Policy, 61, 213-236.

9. Bouma, J. (2006). Slikken: Hoe ziek is de farmaceutische industrie?. Amsterdam: Uitgever L.J. Veen.

10. Bovens, M. A. P. (2005). Public Accountability. In E. Ferlie, L. E. Lynn, \& C. Pollit (Eds.), The oxford handbook of public management (pp. 182-208). Oxford: Oxford University Press.

11. Caron-Flinterman, J. F. (2005). A new voice in science. Patient participation in decision-making on biomedical research. Amsterdam: Vrije Universiteit.

12. Cawson, A. (1986). Corporatism and political theory. Oxford: Basil Blackwell.

13. Clarke, J., Newman, J. E., Smith, N., Vidler, E., \& Westmarland, L. (2007). Creating citizen consumers: Changing publics and changing public services. London: SAGE Publications.

14. Collins, S., Britten, N., Ruusuvuori, J., \& Tompson, A. (2007). Patient participation in health care consultations: Qualitative perspectives. Maidenhead, New York: McGrawHill Open University Press.

15. Couto, R. A. (2001). The third sector and civil society: The case of the "YES" campaign in Northern Ireland. Voluntas: International Journal of Voluntary and Nonprofit Organizations, 12, 221-238.

16. Coxall, B. (2001). Pressure groups in british politics. Essex: Pearson Education Limited.

17. Crawford, M. J., Rutter, D., Manley, C., Weaver, T., Bhui, K., Fulop, N., et al. (2002). Systematic review of involving patients in the planning and development of health care. British Medical Journal, $325,1263-1267$.

18. Epstein, S. (2008). Patient Groups and Health Movements. In E. J. Hackett, O. Amsterdamska, M. Lynch, \& J. Wajcman (Eds.), The handbook of science and technology studies (pp. 499-539). Cambridge, Massachusetts, London: The MIT Press.

19. Evers, A. (1995). Part of the welfare mix: The third sector as intermediate area. Voluntas: International Journal of Voluntary and Nonprofit Organizations, 6, 159-182.

20. Goudriaan, G., \& Goris, A. (2007). Naar een volwaardige marktpositie van patiëntenorganisaties. Leiden: STG/HMF.

21. Grant, W. (1989). Pressure groups, politics and democracy in Britain. New York, London, Toronto, Sydney, Tokyo: Philip Allan.

22. Grit, K., Van de Bovenkamp, H., \& Bal, R. (2008). Positie van de zorggebruiker in een veranderend stelsel. Een quick scan van aandachtspunten en wetenschappelijke inzichten. Rotterdam: iBMG.

23. Hanley, B., Truesdale, A., King, A., Elbourne, D., \& Chalmers, I. (2001). Involving consumers in designing, conducting, and interpreting randomised controlled trials: Questionnaire survey. British Medical Journal, 322, 519-523.

24. Harrison, S., \& Mort, M. (1998). Which champions, which people? Public and user involvement in health care as a technology of legitimation. Social Policy \& Administration, 32, 60-70.

25. Helderman, J.-K., Schut, F. T., Van der Grinten, T. E. D., \& Van de Ven, W. P. M. M. (2005). Market-oriented Health Care Reforms and Policy Learning in the Netherlands. Journal of Health Policy, Politics and Law, 30, 189-210.

26. Hewlett, S., De Wit, M., Richards, P., Quest, E., Hughes, R., Heiberg, T., et al. (2006). Patients and professionals as research partners: Challenges, practicalities, and benefits. Arthritis and Rheumatism, $55,676-680$.

27. Jones, K. (2008). In whose interest? Relationships between health consumer groups and the pharmaceutical industry in the UK. Sociology of Health \& Illness, 30, 929-943.

28. Klijn, E. H. (1994). Policy networks: An overview. Theoretical background and main characteristics of the policy network approach. Working paper.

29. Klop, R., Van Kammen, J., \& Van Eck, E. (2004). Patiënten doen mee bij ZonMw!. Medische Antropologie, 16, 5-19.

30. Koopmans, R. (2003). Good intentions sometimes make bad policy: a comparison of Dutch and German integration policies. In R. Cuperus, K. A. Duffek, \& J. Kandel (Eds.), The Challenge of diversity: European social democracy facing migration, integration and multiculturalism. Innsbruck: StudienVerlag.

31. Leys, M., Reyntens, S., \& Gobert, M. (2007). Patiëntenparticipatie in het gezondheidszorgbeleid: Een literatuuroverzicht en verkenning van Internationale en Belgische initiatieven. Brussel: Koning Boudewijnstichting. 
32. Lofgren, H. (2004). Pharmaceuticals and the consumer movement: The ambivalences of 'patient power'. Australian Health review, 28, 228-237.

33. Mair, P. (2006). Ruling the void? The hollowing of Western democracy. New Left Review, 42, $25-52$.

34. Nederland, T., \& Duyvendak, J. W. (2004). De kunst van effectieve belangenbehartiging door de patiënten-en cliëntenbeweging: De praktijk. Utrecht: Verwey-Jonker insituut.

35. Nederland, T., Duyvendak, J. W., \& Brugman, M. (2003). Belangenbehartiging door de patiënten-en cliëntenbeweging: De theorie. Utrecht: Verweij-Jonker instituut.

36. Newcome Research \& Consultancy B.V. (2006). Van goed naar groter: Een beleidsgericht onderzoek naar de groeimogelijkheden van patiënten- en gehandicaptenorganisaties in Nederland. Enschede/ Amsterdam.

37. NPCF. (2008). Jaarbericht 2007. Utrecht: NPCF.

38. Oudenampsen, D., Nederland, T., Kromontono, E., Pepels, R., Sonneveld, R., \& Stilstette, M. (2007). Patiënten- en Consumentenbeweging in Beeld: brancherapport 2006. Utrecht: Verwey Jonker Instituut, Prismant.

39. Oudenampsen, D., Kamphuis, H., van Dongen, M. C., Homberg, J., \& Kromontono, E. (2008). Patiënten en Consumentenbeweging in Beeld: brancherapport 2007 de categoriale organisaties. Utrecht: Verwey- Jonker instituut.

40. Oudenampsen, D., Kamphuis, H., Lammerts, R., Homberg, J., \& Kromontono, E. (2008). Patiënten en Consumentenbeweging in Beeld: brancherapport 2008 de categoriale organisaties. Utrecht: Verwey- Jonker instituut.

41. Putnam, R. D. (2000). Bowling alone: The collapse and revival of American community. New York, London, Roronto, Sydney: Simon \& Schuster Paperbacks.

42. Rijkschroeff, R. A. L. (1989). Ondersteuning van participatie in de geestelijke gezondheidszorg. Amsterdam: Universiteit van Amsterdam.

43. Rijkschroeff, R., Duyvendak, J. W., \& Pels, T. (2003). Bronnenonderzoek Integratiebeleid. Utrecht: Verwey Jonker Instituut.

44. Rijn van Alkemade, E. M. (2005). Sponsoring van patiëntenorganisaties door de farmaceutische industrie. Utrecht: DGV Nederlands instituut voor verantwoord medicijngebruik.

45. Ross, E. C. (1999). Report from the field regulating managed care: Interest group competition for control and behavioral health care. Journal of Health Politics, Policy and Law, 24, 599-625.

46. Sattoe, J. (2009). Belangenbehartiging belicht: een dubbelrol voor PGO-organisaties. Bachelor thesis, Rotterdam: Erasmus University.

47. Schut, F. T., \& De Bruijn, D. (2007). Collectieve zorgverzekeringen en risicoselectie. Rotterdam: iBMG.

48. Skocpol, T. (2003). Diminished democracy: From membership to management in American civic life. Norman: University of Oklahoma Press.

49. Syrett, K. (2003). A Technocratic Fix to the "Legitimacy Problem"? The Blair Government and Health Care Rationing in the United Kingdom. Journal of Health Politics, Policy and Law, 28, 715-746.

50. Trappenburg, M. J. (2008). Genoeg is genoeg. Over gezondheidszorg en democratie. Amsterdam: Amsterdam University Press.

51. Tweede Kamer (Parliamentary Proceedings) 1982-1983. 16771, no. 14.

52. Tweede Kamer (Parliamentary Proceedings) 1991-1992. 22702, no. 2.

53. Tweede Kamer (Parliamentary Proceedings) 2005-2006. 30482, no. 2.

54. Vaillancourt Rosenau, P., \& Lako, C. J. (2008). An experiment with regulated competition and individual mandates for Universal health care: The New Dutch health insurance system. Journal of Health Politics, Policy and Law, 33, 1031-1056.

55. Van de Bovenkamp, H. M., \& Trappenburg, M. J. (2009). Reconsidering patient participation in guideline development. Health Care Analysis, 17, 198-216.

56. Van de Bovenkamp, H. M., Grit, K., \& Bal, R. (2008). Zaakwaarnemers van de patiënt. Rotterdam: iBMG.

57. Van de Bovenkamp, H. M., Grit, K., \& Bal, R. (2008). Inventarisatie patiëntenparticipatie in onderzoek, kwaliteit en beleid. Rotterdam: iBMG.

58. Van de Bovenkamp, H. M., Trappenburg, M. J., \& Grit, K. (2010). Patient participation in collective health care decision-making: The Dutch model. Health Expectations, 13, 73-85.

59. Van Veenendaal, H., Franx, G. C., Grol, M. H., Van Vuuren, J., Versluijs, M. M., \& Dekhuizen, P. N. R. (2004). Patiëntenparticipatie in richtlijnontwikkeling. In J. J. E. van Everdingen, J. S. Burgers, 
\& W. J. J. Assendelft (Eds.), Evidence-based richtlijnontwikkeling. Een leidraad voor de praktijk (pp. 48-62). Houten: Bohn Stafleu Van Loghum.

60. Van Wersch, S. F. M., \& Van den Akker, P. A. M. (2005). Cliëntenparticipatie bij multidisciplinaire richtlijnontwikkeling in de GGZ: Ervaringskennis is geen kennis!?. Utrecht: IVA.

61. Warren, M. E. (2003). The political role of nonprofits in a democracy. Society, 40, 46-51.

62. Williamson, P. J. (1989). Corporatism in perspective: An introductory guide to corporatist theory. London: SAGE Publications.

63. Zijderveld, A. C. (1999). The waning of the welfare state: The end of comprehensive state succor. New Brunswick, London: Transaction Publishers. 